\title{
Professional closure by proxy: the impact of changing educational requirements on class mobility for a cohort of Big 8 partners
}

\author{
Rachel F. Baskerville \\ Victoria University of Wellington \\ P O Box 600, Wellington,
}

New Zealand

e-mail: rachel.baskerville@vuw.ac.nz

There was some further slight re-editing; it was then published in Accounting History 2006

\section{Acknowledgements}

The primary acknowledgement for this study is to those interviewed in the Oral History project; for their encouragement, enthusiasm and their time. The author also acknowledges the information provided by Dave Guerin (Education Directions Limited, Wellington), constructive comments offered by the anonymous referees for this Journal, University colleagues and conference participants.

\begin{abstract}
Closure events impacting on class mobility may include mechanisms initiated by bodies other than the professional body. The research examines if the introduction of full-time study requirements at universities for aspiring accountants effectively introduced a closure mechanism in the accounting profession. Data was derived from an Oral History study of partners in large firms. The younger partners (born after World War II) completed full-time degree study at university, but did not provide evidence of class mobility into the profession. The older cohort, born between 1928 and 1946, completed part-time studies only, few completed a degree, and, in contrast to the younger cohort, shows a perceptible upward movement from lower socio-economic classes into the professional class. This suggests that changing the preferred educational routes for new accountants entering the large CA firms compromised the 'stepping stone' function of accounting as a portal into the professional class.
\end{abstract}

\section{Introduction}

Historical studies of the dynamics of closure strategies by the accounting profession have focussed on institutionalised actions by professional bodies, particularly with respect to entry requirements. The objective of this study is to demonstrate that closure studies of the accounting profession can usefully be extended to include consideration of closure mechanisms initiated by bodies other than the professional body. There have been few studies on closure by proxy. A closure event, impacting on the membership or potential membership of a professional body, can occur by proxy when the professional body itself witnesses, but does not directly initiate, the closure mechanism. 
This research focuses on the question: did the introduction of full-time study requirements at universities for aspiring accountants effectively introduce a closure mechanism for the profession? In the USA it had been considered that "higher educational standards would serve as an instrument of professionalization and, simultaneously, professional purification" (Auerbach, 1976, p.94). This leads to consideration of the extent to which developments in New Zealand paralleled debate concerning professional education in the USA, in particular the well-documented shifts in closure mechanisms in the legal profession. A further objective of this research is to respond to the call by both Chua and Clegg (1989), and Walker and Shackleton (1998), that closure theorists should pay more attention to the detailed explanatory 'tracking' over time and space of the 'life and death' of one or a set of closure strategies. One manner in which closure may be demonstrated is when it impacts on class mobility.

These research objectives are met by examining both family data and individual educational histories of accountants who entered the profession both before and after the introduction of full-time study requirements at universities. This study uses interview narratives from 40 partners in the biggest accounting firms ${ }^{[1]}$. All these partners qualified for their chartered accountant status in New Zealand between 1940 and 1975. This information was supplemented with historical records; in particular, articles in the practitioner journal concerning this change in educational opportunities.

This study suggests that a closure event was activated when the universities changed their commerce subject timetabling from part-time to requiring full-time attendance. There was also a change in preferred educational routes for new entrants by large firms. Although these results are from a small sample, they are significant, firstly, because they provide a rare insight into inter-generational mobility in the accounting profession. Secondly, few previous studies of class mobility have examined movements between classes based on the mature career achievements of the sons. Most large-scale class mobility studies in sociological fields are based on certificates at the time of the son's marriage that do not offer data concerning further career development of those studied (Walker (1988) being an exception). The micro-approach illustrated in this study may merit further application in other jurisdictions.

In order to review whether or not the introduction of full-time study requirements at universities for aspiring accountants effectively introduced a closure mechanism for the profession, this review will:

${ }^{[1]}$ The large firms in New Zealand included all but one of the Big 8: Price Waterhouse, Coopers and Lybrand, Deloitte Haskins Sells, Peat Marwick Mitchell, Touche Ross, Kendons KMG, Ernst and Whinney, and Arthur Young. Some partners were also in Lawrence Anderson Buddle, which merged partly with Deloittes and partly with Price Waterhouse. Arthur Andersen was not represented in New Zealand, apart from an affiliation to Lawrence Anderson Buddle up to 1986. McLeod Lojkine and Associates, a 5-partner firm that splintered off from the Auckland office of Peat Marwick Mitchell, later represented Andersens. 
1. Examine the early years of the New Zealand Society of Accountants (the Society). The concept of closure, and its occurrence in the accounting profession, will then be reviewed, and also theories of class mobility, and mobility within the professional classes. This draws attention to the issue of the importance of education in rates of class mobility.

2. Describe the New Zealand context, and the history of class in the development of New Zealand will be briefly considered. The method for this research will also be described.

3. Review results from the interviews, relating the educational experiences and debates, and provide historical reflections of the students in both part-time and full-time study.

4. Review the impact of this change on class mobility for the small number of interviewees. This will then lead to the discussion and conclusion.

\section{Early educational requirements of the New Zealand Society of Accountants: the 'open door'.}

The New Zealand Society of Accountants (the Society) was formed by the New Zealand Society of Accountants Act of 1908. The new Society offered membership to all accountants who had been members of the two parent bodies ${ }^{[2]}$ and others in public practice. Although this entrée was a very "wide door", with no qualification required, it applied only to members of the new body when it was first established. Thereafter, there were educational pre-requisites for new members that had not been demanded of the initial membership.

An early article, addressing the ideal requirements for a business career, considered it preferable that students aspiring to the profession in New Zealand should complete their academic studies while working, and no advantage was seen in attending university or technical colleges full-time. "Let theory and practice go hand in hand" (Thompson, 1924, p.298). The Society did not require a degree before students began work as an accounting clerk, and they all worked full-time while completing required studies, either at a Technical College, a Business College, or a University College within the University of New Zealand.

At this stage aspiring students had to complete either matriculation (the entry examination for university) or the Preliminary Examination. The Preliminary Examination was discontinued after 1931, and all students had to complete matriculation ${ }^{[3]}$ before being permitted to sit examinations for the Society.

\footnotetext{
${ }^{[2]}$ These were the New Zealand Accountants and Auditors Association, and the Incorporated Institute of Accountants of New Zealand (formed in 1894).

${ }^{[3]}$ The commercial colleges (evening classes) continued to offer matriculation for those who had not completed it at school up into the 1960s.
} 
The processes of professionalisation and credentialism in New Zealand appeared different, for example, from those for the Society of Accountants in Edinburgh and the Institute of Accountants and Actuaries in Glasgow. The Scottish bodies not only required a period of apprenticeship, but also compulsory attendance at university law classes and entrance that was based on written and oral examinations (Walker, 1988; 1991). In the Society of Accountants in Edinburgh, the examination failure rate in the early years of the professional body was 53.3\% (1850-1871, Walker, 1988, p.159). Success depended on a set of conditions identified by Walker (1988, p.198) as favouring apprentices of higher social status.

In New Zealand the process of credentialisation was that the Society set examinations, which were administered by Universities and Business Colleges. After the early 1950s the Society reached an agreement with Universities as to which papers would be equivalent to Society papers. This developed into a process of accreditation of specific papers taught and examined by all the tertiary education providers. This has continued in much the same form up to the present day.

Similar to the Scottish data, pass rates for accounting examinations in New Zealand were very low. This may have been a barrier to those with poor secondary education and heavy work commitments. However, the expense of indenture fees was spared for New Zealand entrants. There was evidence in interviews of the importance of personal invitation, and also some religious connection in the employment of some of the interviewees:

"Partners and staff were selected by accident, when you look back. They were Presbyterians; I'm not, but they were. Both the Hastings and Gisborne offices had a very strong Presbyterian bias. There was no deliberate religious connection or anything like that, but it happened that the partners in their 30s and so on taught Bible class. When you are in that environment and you are looking for a good, young up 'n coming lad, well of course it was the lad who was shining in Bible class. So they would offer him a job. By accident - I'm quite sure it wasn't by design - they got some very good quality people as young boys." Partner in McCulloch Menzies predecessor firm of Touche Ross - born 1940

Another remembers Charles Francis, partner in Adamson Francis and Harrington, and a Bible Class leader in Invercargill:

"I was working in the bank, and my Bible class leader, who was a chartered accountant, came into the bank one day...and said, 'I see you've got your exams [university entrance]'. I said I was pleased about it. He asked, 'Have you ever thought of going into accountancy? You could have a very good future'. What I really heard was... that I wouldn't have to go to Wellington [for the bank], where I didn't want to go. So I said I'd be interested. My Bible class leader invited me to come and see him on Saturday.

I went round - he was thinning carrots in his garden - and we arranged a job, and I said 'But don't I have to fill in an application form?' 'No, ' he said, 'just turn up'. I had to give a month's notice, so we worked that out. We did talk salary, and he told 
me that he wasn't going to pay me too much, 'cos...I'd be trained. I was very happy. I was there for 42 years. Partner in Ernst and Whinney, born 1929

Although such personal invitations do not constitute institutionalised closure, they can be equally effective in preferential selection for a particular social class.

\section{Theoretical contexts}

\section{Closure in professions}

The notion of closure by professions originated from Weber's proposition that social groups seek to regulate market conditions in their favour, despite competition from others, by restricting access to opportunities (Weber, 1968). Murphy (1984) extended closure theory to include studying the relationships among different rules of closure, and how rules of closure are constructed. Taking closure from the point of view of those already gainfully employed in a professional activity, Freidson advocates the use of Marcia Freedman's term "Labor market shelter' to characterize the closure (Freidson, 2001, citing Freedman, 1976, pp.114 - 116). However, the type of closure discussed in this study is determined to be a derivative form of exclusion according to Murphy's three types of closure, i.e. derived from the principal form of exclusion (an accountant must have passed the required papers), but is not identical to it. Closure yields social and economic rewards, as Larson particularly demonstrated with respect to the medical profession (Larson, 1977). In Collins' discussion of market closure and conflict theory, his description of occupational closure identifies that education plays a crucial role. "The modern 'high professions' tend to stake their status honour on their educational qualifications" (1990, p.37). He suggested that, compared with the previous apprentice-based model for professional education, university qualifications tended to have a lesser focus on technical skills, these being learned after education was completed.

This is in contrast to the earlier apprentice-based systems, such as the establishment of Mechanics' Institutes in the USA, founded around 1820-1870. These functioned as both a school and a professional association, combining practical with technical education (Stevens, 1983, p.43). It was only much more recently that those two aspects were divided physically and temporally for lawyers, accountants, and other professionals. Studies of the US professions provide a base for closure studies; such as Miranti (1990) and Loeb and Miranti (2004). These document the differing constructions of accounting knowledge by both the universities and the practitioners, such as Dutton, Sprague and Haskins, promoting different ideas about the nature of the accounting and the means of improving accounting practice. Miranti and Loeb (2004) fully document the close relationship between the most prestigious universities, the professional bodies, and large firms. Miranti (1990) described how in the first period of professional activities (1880 - 1900) social status was an important issue. "Elite status was usually associated with white, Anglo-Saxon, middle-class origin in the Northeast. 
This helped to assure acceptance among other elites who shared the same heritage. It also implied greater access to educational opportunities to develop the skills for professional life" (1990, p.13).

There were also studies by Abbott, 1988, Auerbach, 1976, and Stevens, 1983, on the legal profession; Stevens, 1971, on the medical profession; and Calvert, 1967, on the engineers. Auerbach's examination of the response of elite lawyers to social change was a detailed examination of their struggle to retain dominance based on ethnicity and class. Although in the first two decades last century, "law schools were pressured by those who demanded a freely swinging door to the profession" (Auerbach, 1976, p.88), the Law Schools at universities had perceived their function in elitist terms, leaving night school to serve 'aspiring urban Lincolns' (ibid, p.88). Such processes of professional democratization that survived from the Depression years last century reversed during anti-dissident resurgence during the Cold-War years (ibid, p.7).

There are three major differences between the drivers to the closure cycles in the United States compared with the jurisdiction under examination in this study:

1) Immigration in the 1940 s and 1950 s to New Zealand was overwhelmingly from the 'home' country (United Kingdom), also the home of the 'A-Class' accounting professional bodies, such as the Institute of Chartered Accountants of Scotland. Therefore immigration movements from the United Kingdom were not largely seen as originating from a foreign soil. This sentiment was also reflected with travelling scholarships (one every two years) for bright young New Zealand accountants to the UK. This contrasted with the USA where the patterns of twentieth-century immigration were seen as 'diluting the purity' of the professions (Auerbach, 1976).

2) If some of the early accounting partnerships had any affiliation at all it was to offices in Europe and the UK, thus strengthening their knowledge of the education systems in those countries, and ensuring there was pressure to keep educational requirements in New Zealand matched with those countries. Immigrants were not seen as 'less' educated, as occurred with early and midtwentieth century immigration to the US from Eastern Europe.

3) In New Zealand class was not an issue of itself, as detailed further in this study: the self consciously egalitarian ethos of the early years of the twentieth century meant that professions did not perceive themselves as being weakened by a lack of class closure mechanisms, which has been documented as occurring in the US legal profession, in particular by Stevens (1983) and Auerbach (1976) 
In contrast to the USA, this study is examining a closure event that was driven by a desire to strengthen the educational foundation of aspiring accountants, not exclusion of a particular class or ethnicity. This study has closer parallels with the examination of closure in the Australian accounting profession in Victoria by Carnegie and Edwards (2001). They examined the 45 founder members of the Incorporated Institute of Accountants, many of whom had other occupations before they became accountants. It was apparent that the founders moved into public practice both to distinguish themselves from clerks and bookkeepers, and to exploit the market value of the specialist recognition.

Another study of the 1886 - 1903 period in Australia by Chua and Poullaos (1998) identified three key tensions during the professionalisation of accounting in Australia at that time:

- Those associated with the emerging colonial markets for accounting services

- A fledgling local profession subject to competition from and between the various United Kingdom bodies; and

- The emergence of local and national governmental agencies with the objective of establishing viable civic and business operations.

Chua and Poullaos argue that the notion of closure as used in studies of the profession in the old countries is "too blunt a descriptor of either associational intent or outcome" (1998, p.156). The four factors they identify as affecting issues of closure in Australia are also mirrored in New Zealand:

1. Associations seek and achieve different levels of market influence at different periods.

2. The mechanism of achieving closure is not static.

3. The set of strategies that may be used to achieve closure depends on the resources of the associations; this is shaped by and also shapes ongoing classparty-status struggles within each association.

4. Professionalisation efforts by accountants were strongly influenced by an opening of borders; that is, the long-distance influence from the United Kingdom to Australasia did not result in clones of the United Kingdom bodies in these outlying colonies, but rather, new types of professional organisations.

The problems appear the same for these earlier associations in both New Zealand and Australia: having respectable examinations, demanding testimonials, and establishing disciplinary mechanisms. However, these were not enough to appease those critics of the 
emerging profession who claimed that these bodies would exclude 'worthies' if they did not permit membership to experienced practitioners without requiring them to do examinations. When the associations allowed such accountants to be members, they were accused of being too liberal and, later, of setting higher standards for new members than for earlier entrants (1998, p.169). In this study, the mechanisms of achieving closure are clearly not static, and may also be found to operate by proxy in the actions of other institutions. In order to demonstrate a closure mechanism that resulted in changing rates of class mobility, a brief review of extensive studies of class mobility is required.

\section{Class mobility}

Societies characterised by high mobility rates are expected to have a low level of classconsciousness; openness is a key element in explaining the degree of class-consciousness which exists (Pearson and Thorns, 1983). Growth of class awareness was tied to beliefs about the degree of ease of upward movement into higher status and elite positions. Erikson and Goldthorpe offer a lengthy reappraisal of theories on social mobility (1992: The Constant Flux) and revived a fresh interest in class mobility studies, with detailed analysis of nine European countries, examining

- Trends in class mobility

- Social fluidity within class structures

- Absolute rates of class mobility

- Class mobility of women

- Work-life and inter-generational class mobility.

They suggest more or less complete unanimity among class and social mobility theorists on the following three-part proposition, regarding industrial societies compared with preindustrial ones (Erikson and Goldthorpe, 1992, p.5):

1. Rates of social mobility are high and upward mobility predominates over downward mobility

2. Mobility opportunities are more equal, in the sense that individuals of differing social origins compete on more equal terms to attain (or to avoid) particular destinations, and

3. Both rates of mobility and the degree of equality of opportunity tend to increase.

Erikson and Goldthorpe further postulate that class mobility contributes to stability in modern industrialised nations by legitimizing prevailing class and status inequalities; while reducing the potential for collective class-based radical action protects democracies. 


\section{Mobility and intra-class relativity within the professional classes}

Few previous studies have addressed mobility within the professional class. In spite of the robust scholarship on the professions from American studies, this angle has not been extensively considered. Walker's analysis of occupational status and mobility (1998, p.240) suggested that the rejections by members of the Society of Accountants in Edinburgh of their own profession as being suitable for their sons "lie in the quest for status improvement". This is one of the rare studies which documented intra-class mobility. If accounting fulfils the anecdotal attribute of being a 'stepping-stone' into the professional class, research would be required to further demonstrate:

- A hierarchy of professions within the professional class, with accounting 'lower' than law, medicine, the church, etc. An important question would then concern the determination of the relative status of new professions, such as financial analysts and advisors, information technology experts. The relative position of banking within the hierarchy of the professional class is also critical to the particular cohort in this study.

- A higher rate of upward class mobility into the accounting profession than into other professions, that is, a higher rate of the children of blue-collar workers and tradesmen moving into the accounting profession than into law or medicine, etc. This would require a large amount of inter-generational data based on information other than marriage certificates, long preferred by sociologists studying class mobility.

- Inter-generational retention within the professional class, that is, do children of accountants move into other professions rather than stay in accounting or show downward mobility? Again, this would require longitudinal data based on the midlife career achievements of three generations ${ }^{[4]}$.

Within studies of the accounting profession, Walker's study of the professional status of Scottish accountants made an interesting distinction between Edinburgh and Glasgow chartered accountants; the latter in the late nineteenth century were considered to be on a lower level, due to the closer connections with trade and commerce (1988, p.17). Public accounting in the USA (as distinct from general accounting) was considered to be "making a directed effort to become a higher profession, to dwell in that rarified atmosphere of the elite professionals of medicine, law, dentistry and university teaching" (Montagna, 1974, p.62). Historically, early professional bodies were clearly recognised as organized elites (Lee and Walker, 1996), but in the more recent period, it was less certain. Montagna's book was based

\footnotetext{
${ }^{[4]}$ The Biographical Information forms, which are usually lodged with transcripts and tapes in Oral History Archives in USA, United Kingdom and Australia and other jurisdictions, have details of fathers' and sons' mature occupations; these would provide an extensive database for studies of intraprofessional mobility and also provide a much larger sample than this research project.
} 
on a large 1965 research project in the USA, and he anticipated that CPAs would 'make it', due to efforts in the 1970s. Montagna discusses whether or not accountants are part of a strategic elite (ibid, 180), and suggested that although the work of accountants places them as part of a strategic elite, this is often not perceived as such.

If the stepping-stone idea holds, then upward intra-class mobility would be observed. In an examination of father/son careers subsequent to the establishment of the Society of Accountants in Edinburgh in 1853, Walker determined that 40 of its original members had fathers in occupations considered to be above the status of accountants (1988, p.15). Very few of the New Zealand partners interviewed had children who also entered the accounting profession $^{[5]}$, although most of their children achieved university degrees and many entered the legal, engineering and medical professions. Absent among occupational choices of their children were architecture, the church, the actuarial profession, or university educators. Further studies focussing on a larger sample with data from at least three of more generations would provide further insights into this "stepping-stone" metaphor for accountancy among the professional classes.

\section{The importance of education in rates of class mobility}

The education system and certain educational routes may be viewed as the main channels for mobility, but can also be regarded as the main channels for non-mobility. Hopper suggested there appears to be a failure to recognize the independent effects of educational routes in studies of class mobility statistics and rates; to do this would require identification of educational systems in the different jurisdictions (Hopper, 1981). Such an approach is facilitated by considering the different views on the manner in which universities contributed to the construction of such routes. Abbott (1988, p.196) describes the alternative viewpoints of universities:

- Being institutions that rewarded and legitimated effort, talent, and merit of the bourgeois class, enabling it to defeat a gentry that controlled other institutions;

- Standing distinct from the profession during its "professionalizing" period;

- Serving as legitimators of expert knowledge; or

- Becoming an area for inter-professional competition.

\footnotetext{
${ }^{[5]}$ The question of following a father's footsteps raises the issue of the anti-nepotism rules in large accounting partnerships. Although outside the domain of this report, it was apparent from Oral History interviews that anti-nepotism rules had evolved to the extent where many partnership deeds in large firms forbade partnership status to the son of a partner. Although interviewees agreed that this is a sharp contrast to other professions, explanations by the interviewees for the justification and origins of this rule were various.
} 
In this study, the New Zealand universities were standing distinct from the profession. This position had been accentuated by the cessation of the practice by the New Zealand Society of Accountants of making grants to the universities to assist with the development of their accounting programmes, when such programmes were offered in 'after-hours' classes. Education may have the nature of a 'skills inheritance': not only property but also skills can be passed to children by the investment of parents in education and training and in the type of schooling received (Western, 1994). It is not disputed that parents who are experts are also typically in a better position to be aware of the requirements for academic success and to provide a home environment to facilitate this success. A further advantage to offspring is that of familial socialization: the experience of children in their father's workplace may lead them to value self-employment in a way that children of waged workers do not; i.e. they come to value control over one's own labour power, and the occupational ideology of their father (Western, 1994). In an Australian study, Crook (1997) identified that new studies on occupational mobility show that education, not nepotism, has the greater influence.

From an earlier period, Walker's study of societies of accountants in Scotland in the second part of the nineteenth century illustrated the significance of educational opportunities for marginal middle-class families who aspired upward mobility for their sons (1988, pp.253254). However, entrants to the profession in Edinburgh from semi and unskilled manual origins remained low throughout this period until World War 1. Entrants from lower and middle-class origins increased in the late 1870s, but declined when sons of professional men entered in larger numbers or when educational hurdles were raised in the 1890s (Walker, 1988, p.259).

The New Zealand Government has supported free secondary-school education since 1903 and introduced a minimum school leaving age of 15 in 1944. This brought opportunities to sections of the working classes whose children could secure access to mobility opportunities through acquiring credentials from the formal education system (Pearson and Thorns, 1983 p.131). The very low fees at Universities (averaging $£ 15$ per annum in 1960) eliminated the elitism associated with higher education in the UK (Sinclair, 2000, p.310). The underlying question of the extent to which society is better off with expansion of educational opportunities is not further addressed in this study, but such expansion was an enduring legacy from the policies of the New Zealand Liberal party early in the twentieth century. As noted by Oliver, in New Zealand effective social policy was considered to be that which was conducive to mobility and equilibrium $(1969$, p.175).

If a profession can directly increase educational requirements, or indirectly support another body (such as the educational providers) demanding changes in educational requirements, it increases closure. An underlying assumption of this study is that closure has occurred if there 
are lower rates in upward class mobility, while acknowledging two conditions that may compromise such an assumption. First, much uncertainty exists in the literature concerning the impact of egalitarianism in different jurisdictions on actual mobility rates; and second, if the particular occupation is rising in status then those members of the profession will be achieving class mobility ex post their entry to the profession.

\section{History of class in the development of New Zealand}

Early white settler society in New Zealand, with its enduring links to England and relatively short history, can be described as falling into four major periods: colonial beginnings $1840-$ 1890; the pastoral economy 1890 - 1935; the welfare economy 1935 - 1967, and the post 1967 developmental period. (Pearson and Thorns 1983 p.16). The period of this study covers the 1935 - 1967 years. The entire cohort had begun their university or commercial college studies by 1970. Pearson and Thorns document that the structure of the economy and the constellation of interests responsible for shaping development resulted in a class structure quite different from that found in longer-established industrial societies. The following were distinguishing characteristics:

1. New Zealand society had neither a long-established aristocracy nor a landless peasantry, and had developed a strong notion of egalitarianism. This was strengthened during the long period of sustained economic growth post World War II. However, twentieth century New Zealand society was stratified, and the groups dominant in the 1890s shaped the future class structure.

2. There were major efforts to widen the economic base away from a total dependence on pastoral activities during the 1930s depression.

3. Wartime shortages during World War II also drove the development of a manufacturing base, especially for electronic goods and consumer durables. This growth in manufacturing resulted in a more extensive working class.

The New Zealand historian, Keith Sinclair, described New Zealand as becoming "one of the most self-consciously democratic societies in the world" (1990, p.131), and New Zealand society has been marked by constant class mobility. Industrialization and capital accumulation were so limited that the European ideas of class require considerable modification before they can be used profitably in considering the history of New Zealand society. "Our social evolution has gone on between a high floor and a low ceiling, and between these narrow limits we have had great mobility" (Oliver, 1969, p.164). In spite of the self-consciously democratic nature of New Zealand society, and the mobility postulated by W.H.Oliver, this study suggests that class mobility was constrained when Universities changed their timetable to favour those who could afford full-time study. 


\section{Method}

Data for this study was derived from a larger project, for which the research question, broadly stated, was "Why did the survivors survive: a study of the differential survival among large accounting firms in the 1980s." The objective of interviews was to discuss and review reasons for the survival of the 'Big 4' firms, and to discuss factors that had contributed to the collapse of other large firms in New Zealand in the 1980s. In the process of interviewing partners from large firms for this project, protocol demanded by the Oral History Archive in New Zealand required each interviewee to supply family information (the biographical information form) so other users of the Oral History Archives can later identify clearly each interviewee. In talking through these information requirements, the interviewees described their family background, why they chose accounting, and their educational routes.

Analysis of social mobility had not been the primary objective of interviews, yet this rich information base lent itself to such an ex post focus. The selection of 40 partners for the Oral History project, and the issue of self-selection, is further discussed in Appendix 1. Interviewees were from all the large firms, and from both urban and rural towns and cities. Their fathers' occupations were classified utilising the nine-level hierarchy as proposed by Olssen and James (1999) after analysis of the educational and biographical details. Olssen and James were of the view that small employers and self-employed complicate earlier and more widely applied three-tier models. Their scheme was:

1. Large employers and higher managerial

2. Professionals

3. Semi-professionals

4. Small employers and self employed, sometimes referred to as 'petit bourgeoisie'

5. Official and supervisory

6. "White-collar"

7. Skilled

8. Semi-skilled

9. Unskilled

These types of occupations are applied to the fathers ${ }^{\text {[6] }}$ occupations of the cohort of partners in large firms in New Zealand. The findings from this disaggregation of employment, as in Table 1, will be further discussed. Table 1 utilised six of these

\footnotetext{
${ }^{[6]}$ Apart from one subject, all their mothers were of equivalent or 'lower' occupations. The only exception was one whose father was a hairdresser, and his mother was manager in a tobacco factory.
} 
categories; the "Other white collar", and "Large employers and higher managerial" were not used. "Semi-professional" and "Official and supervisory" were combined, as a solution to the problem of multiple careers on the part of the fathers. "Semi-skilled" and "Unskilled" were also grouped together, as they only appeared in the oldest cohort. The details of the three of the six categories of 'Parents' Occupation' in Table 1 can best be understood with the exact occupations from partners of those interviewed. They are as follows:

1. The eight 'Other Professionals' were: Scientist (x2), Electronics Teacher /Electrician, Barrister/Solicitor, Schoolmaster, Bank Manager (x2), Officer in the Royal Navy.

2. The 12 occupations in the 'Entrepreneur: sole proprietor/ petit bourgeoisie' category were: Retailer/owner (x 6), Manufacturer/Retailer jeweller, Owner/Operator of a Transport business, Importer/Farmer, Orchardist/Farmer, Salesman/Farmer, Factory Manager/Director of a tin-plating company.

3. The three occupations in the 'Official and Supervisory, Semi-professional' category were: Businessman and Stock Agent; Chartered Secretary/Manager of a Municipal Abattoir, and a Stock and Station Agent/Land Agent.

Having established the method for this study, discussion of the results are divided into two sections: firstly, the education experiences of part-time and full-time study, and discussion of the drivers to the change in the University timetabling. Secondly, the degree to which this impacted on class mobility in this cohort is further examined.

\section{Findings (1): Educational experiences and changes}

\section{The part-time students}

All the older part-time students in this cohort undertook their studies by attending lectures or classes either in the morning or late at night, as well as completing a full-time job; or by correspondence while working full-time. Some of them recall how hard it was and, in particular, remember the difficulty in taking summer holidays or leave for special family occasions. Part-time clerks did not pay any type of articling fee to the firm who employed them, and were paid while they undertook their part-time studies. Many of them studied at night classes with business colleges, such as Harles, Hemingways, or Entings. Entings guaranteed that if the student paid $£ 50$ they would pass all the required subjects for the accounting examinations ${ }^{[7]}$. One particular student eventually took 20 years to pass the 12 or

\footnotetext{
${ }^{[7]}$ The heyday of the business colleges was 1900 - 1940; they lost ground to the Universities after the University subjects were more closely aligned the syllabus required by the NZSA after 1946. However,
} 
14 subjects required; he remembers failing his last paper (Auditing) on a second try and Entings would no longer honour the guarantee if he did not pass the last paper on his third try.

The commentary which follows is typical of these recollections:

"I went to Victoria University College as a full-time student for my first year, and [with one other] we were the first full-time students in accounting at Victoria. We were both there for only our first year, but we got four units, one of which was accounting; of course, it was easy for me, having already done it at school... The head of the accounting department was the rather famous Bill Rodger, subsequently Professor Rodger at Auckland.... In the case of Accounting I the lectures were after $5 \mathrm{pm}$, from 5-6pm, three or four nights a week, so everybody, apart from Barry Hume and me, was a part-timer.... I had virtually the whole day free because economics lectures were in the early evening. It was all geared to part-timers. But I became a part-timer myself after that." Partner in KPMG, born 1935

One of the early students who gained a degree went part-time, as his parents had younger children and the family was 'stretched' financially. His father was a Stock and Station Agent; and his mother a nurse. He remembers that all classes were evening classes except English:

"University full-time was not even considered; besides, all the accountants [clerks/students] in Masterton didn't go to university. They did their accounting by correspondence. ... which I did for three years; I botched the first year because I had taken accounting exams on the advice of people I worked for, and later I decided to do a degree...I started again, getting credits towards the degree.

After getting two years of credits, I was going to take Accounting III and Auditing, and such things, and thought it would be too hard to do by correspondence. ... In the middle of 1956 I'd been to a seminar at the university on the 1955 Companies Act, where I'd spent two or three glorious days surrounded by university students, and I loved it. Earlier in the year I'd done ten weeks of military training, where I met university students and had inquired about life in Wellington, the cost, how you lived, and so forth, and in September 1956 I decided to attend university in 1957.

At university, all the classes were in the evening except English I, which was from 8$9 \mathrm{am}$, so the regime was to work down-town, zip up to lectures from 5-8pm or 6-8pm, whatever, and go back to Weir House ${ }^{[8]}$ where the meal had been kept hot, then start the evening study, and then back to work the following morning. There were no professors of accounting then. The classes were crowded, and you sat and wrote what you thought he said, took it home, swotted it up and read the book. It wasn't as expensive as now, but it wasn't as good, either. So that was how one got a degree in those days, and how one got into accounting, but it was better than correspondence." Partner in KMG Kendons born 1937

\section{The full-time students}

What about the experiences of those who started full-time study? The oldest completely fulltime student in this cohort had a professional father, a plant scientist working for a fruitgrowers company. His mother had been a teacher. He recalls clearly the unusual experience of taking course full-time:

they were still valuable for those who worked away from a University City. Both Harles and Entings were closed by 1960 (Guerin, 2005).

${ }^{[8]}$ The only University Hostel. 
"When I went to university, my father and I had planned my whole university career; so I did a BA and a BCom at the same time. I was mixed as to what I would do, but my father always had a strong view that boys should have a professional qualification... At that stage, of course, few people did it full-time. I went through five years full-time, which was very unusual - almost nobody did accounting fulltime all the way through. Right from the age of 10 or 11 I knew I was going to university; it was never debated. Partner in Arthur Young, born 1942.

Another, now a well-known, wealthy and successful businessman, recalls why he also embarked on full-time study whereas most others were part-timers:

"It was about 1962 or thereabouts, and most people who were interested in accountancy would have taken a job and studied part-time. I think ... because I initially struggled at high school ... if it hadn't been for my mother's perseverance I would have continued to struggle... while I was quite good at accounting I struggled at some other subjects, such as English etc. ... if I were to have a real chance I'd be best to go full-time. I put my head down, and I played rugby, seriously, playing for University A. But I also studied hard ... and I completed in three years. In fact, I graduated before I was 21." Partner in Ernst and Whinney, born in 1945

\section{The debate on part-time versus full-time attendance by students}

The shift from part-time study to full-time study occurred at different times in different jurisdictions. In discussing the evolution of legal education in the USA, Stevens noted that although part-time schools had been seen as a democratizing phenomenon, from 1922 on fulltime was seen as more effective. By 1927-28 there were 166 law schools in the USA with 3year full-time courses, while in the same era, the number of part-time students rose from 13,318 in 1919 to 26, 430 in 1926-27 (Stevens, 1983: p.183). The 'night school' reappeared in the 1970s 'bull market for lawyers' (ibid, p.243) but now these were often affiliated to an accredited law school.

For the engineering profession, towards the end of the previous century $(1879-1896)$ there had been 48 appointments of engineer-instructors, and the development of a systematic base of technical knowledge (Calvert, 1967, p. 43). There was then a slow and gradual shift to University instruction, although remaining on part-time schedules.

In New Zealand the major thrust to full-time commerce degrees was an outcome of the report of the 1960 Parry Committee on University Education, sponsored by the Government of the day. This "Report of the Committee on New Zealand Universities" recommended rearranging timetables to require full-time studies, and remodelling degree courses, with only diploma courses for students who attended after work. The universities discontinued offering courses in accounting subjects at times that suited young accountants who both worked fulltime in accounting firms and studied at classes, either early in the morning (8-9 am) or after work (5 pm or later). These changes appeared to result in the reduction of top-level employment opportunities for those who could not afford a full-time university course. Although students could still take part-time business college subjects or correspondence 
courses, they appeared to be relegated to the 'second-tier' of professional aspirants. Issues driving these recommendations were:

1. Failure Rates:

The Parry Report had found the failure rate among part-time students was very high; parttime students also had a much poorer record of completing a degree. 115 graduates at Victoria University (Wellington) from 1953 - 1959 took an average of 8.5 years to qualify. The Report envisaged that the problem of high failure rate would be overcome by putting students on a full-time basis. The following comment was typical of the 'hard slog' recalled by those in the cohort who were part-time students:

"The Varsities were pushing - they wanted full-time students. They said we were there for a meal ticket; that we weren't forming part of the university life; all we did was to qualify. That was right ... true, but what else could you do when training? It was hard; we had lectures four nights a week, and often I did not get home until 9 o'clock; then there was study on top of that; working full-time - it was hard. I remember having no weekend activities during term-time. I used to go tramping in the holidays and weekends, but during term I just worked and studied all the time" Partner in Lawrence Anderson Buddle, later PW, born 1942

\section{Cost}

Students paid fees of only $£ 15$ per annum and the balance of costs for the Universities was derived from Government grant of $£ 100$ on average per student per annum (Budge, 1960). Students who failed repeatedly were seen to be costing the country a large amount. Employers also allowed time off; each failed student represented an expense for them as well, costing from $£ 45$ to $£ 75$ per annum for each employee permitted to undertake part-time study (ibid). Relatively low educational fees charged by universities, and lucrative holiday employment opportunities, also facilitated acceptance of the change to the requirement for full-time study. One of the cohort still recalls the cost-benefit analysis which encouraged him to attend fulltime:

"I was paid $£ 3$ a week all year - paid $£ 12$ monthly by cheque. So after the first year of going part-time to university I decided to go full-time, because I could earn $£ 10$ pound a week in the wool stores over the Christmas holidays. In 1954 and 1955 I attended full-time. Partner in Ernst and Whinney, born 1934

\section{Reciprocity}

In both the United States and United Kingdom, students were increasingly undertaking fulfilment of the requirements through completion of full-time degrees, thus New Zealand standards would have been considered below those of partner jurisdictions, where the Society was seeking reciprocity of credential recognition. In North America, part-time study was 'a thing of the past' (Sidebotham, 1962); in England major accounting professional bodies did not recommend part-time degrees. 
4. "Penny wise and pound foolish?"

Part-time study was an expensive route in that the student deferred both the date of his qualifications and the consequent better salary as a qualified accountant. The average member would take 9 to 10 years of part-time university study; and for a BCom, 11 to 12 years (Sidebotham, 1962). They could therefore lose up to nine years' salary from the delay in the start of their entry to the profession.

\section{The quality of education and staffing at universities}

In addition to the major problems of low pass-rates, there was also a low level of educational attainment of those who passed, and a lack of post-graduate facilities (Cowan, 1960). There was a shortage of staff in accounting departments throughout the country, and full-time timetabling would have caused problems for practising accountants who had traditionally provided the teaching staff at universities. It was questioned whether they could secure sufficient and regular time to undertake teaching while servicing their clients (Fippard, 1960). Such practitioner-teachers were frequently recalled in interviews:

"There was a lot of discussion about it, and I think one of the issues was whether university staff would be as well qualified to teach as part-time teachers had been. When I did accountancy...for Accounting II we had Bill Steele - a well-known partner in W H and R J Nankervis [a forerunner to Arthur Young] - and we had the Chief Accountant for A S Patterson and Company. So we had two, very keen, wellexperienced people teaching Accounting II. In Accounting III we had the Chief Accountant or Financial Director of Whitcombe and Tombs who took us for Financial Accounting. And for Tax we had the leading tax practitioner in Wellington, ...." Partner in KPMG, born 1935

Foundations of a professional career were also considered best laid in the 20s, not 30s. Parttime study dulled the desire for advanced work, it was anti-social, and not enjoyable. Sidebotham recommended that at least the first two years should be full-time, then two years part-time, and then a fifth year if desired to complete a BCom. "The New Zealand universities are equipped to give the profession in this country the most comprehensive education service in the Commonwealth. If they fail to do so it will be because the profession and the schools continue to regard than as high-grade night schools" (Sidebotham, 1962, p.325).

The solution proposed was that universities would offer full-time study programmes for commerce students. Cowan considered that the role of the Society should also be to encourage students to study full-time. The Society had meantime established the 'Long Term Education Committee' (chaired by Norman Fippard). Their report recommended that the professional body should not insist on a rigid method of tuition. The differing points of view had to be reconciled quickly to avoid fragmentation of the profession (Editorial, The Accountant's Journal, February, 1962). 
One of those interviewed, who was later involved with the setting of education standards by the Society, remembers clearly the debate concerning the change from part-time to full-time studies, and the reasons for it.

"[Q.: Do you remember what was driving it?] There were several meetings of the Branch and the Students Society about it, and the older fellows were violently against it, because it was like an apprenticeship in our day. 'How could you possibly learn, ... go into business if you hadn't practical experience?' The argument of the university people was 'Give us the guy, and he'll get his practical experience in six months after his full-time study, and he'll be better adjusted to pick up these things. You are holding the fellow back by insisting that he spends five or six years', - five or six years was what I took to get my degree part-time. There's no question the universities were right - they were absolutely right. The students coming out after full-time study were far brighter than we were. They did things in their first year of full-time study that we did in our second and third years, when part-time.

[Q: There was some feeling it was really for the convenience of staff at the university?] Yes, because the Accounting Department was a sub-department of Economics... and all the lecturers were part-time - Bill Rodger, and Dick Wild - a lot of the lecturers were part-time and came in the evenings and spoke to us, and they were all senior members of the profession in Wellington. But, no, those of us who studied part-time were a bit worried because [full-time students] would all be 'sissies'. 'Why should they go full-time and why couldn't they get out and work?' You know - the old idea. But, no, [the universities] were right. Absolutely." Ernst and Young partner, born 1928

Some comments in the debate of the early 1960s reflected awareness that full-time study may hinder class mobility. One student correspondent suggested that full-time study was unduly discriminatory against those not fortunate enough to have parents rich enough to support them while they attended university full-time (King, 1962); Professor Sidebotham had also noted that "there lingers a nostalgia about the concept of the poor working boy, putting his leisure to good account by studying for accountancy examinations, and eventually emerging triumphant, forged in the fires of adversity"(Sidebotham, 1962, p.323). This resonates with the USA in 1905, when one third of law students attended night schools; the Dean of one described such students as being "men of heroic mould" (Auerbach, 1976, p.98).

Such a route was not forbidden by the Society, but closure effectively occurred due to two actions by other stakeholders:

(a) Universities rearranging their timetables, so that students doing subjects at universities had to study full-time; and then

(b) Firms appearing to shift their recruitment policies to favour university graduates.

In spite of the small numbers in the younger cohort of this Oral History study, and the selection of partners from only large firms, these interviews and biographical data clearly suggest these firms changed their recruitment policies when universities offered the required subjects at times that would not suit part-time students. If there were such changes in the 
recruitment policies of the large firms, this suggests that the benefits outweighed the disadvantages to all groups affected by this change in the policies of universities. Students who could not afford to go full-time continued on the part-time route; the debate was relatively quickly resolved.

One partner who had taken the part-time route recalled that in fact when these new full-time graduates were entering the profession in the early 1970s there was a demand for more audit juniors. As he stated:

"At that time it was a scramble to get staff, at a time when audit work was changing and our firm sought to increase its staff/partner leverage in audit. Thus of necessity, with insufficient graduates in the market, we recruited students, preferably those with good results and not too far from completion of their degrees. As soon as possible we then recruited only graduates, and we were competing with other large firms for the best graduates."

\section{Findings (2): The impact of a closure mechanism on class mobility}

From the interviews in this Oral History study, the parents' occupations were categorised according to the Olssen and James system. Table 1 illustrates the type of tertiary study undertaken by this oral history cohort, birth dates, and class of parental occupation. The average age data suggests that the ten-year difference between the full-time and part-time students implicitly impounds other significant factors, such as changing macro-economic and labour market conditions. Table 1 provides data demonstrating that:

(a) The younger cohort of students studying full-time showed less upward class mobility than the older part-time cohort. $40 \%$ of the older group came from blue collar, tradesman or supervisory occupations.

(b) The younger group who studied full-time all had parents in the entrepreneurial or professional classes

(c) Those students born after 1942 all chose to study full-time and gained a degree even though a degree was not necessary for membership requirements of the Society. There was still the opportunity for students to complete required subjects part-time at evening classes. But none of this younger cohort, who all ultimately became partners in these large firms, undertook this route.

These results are in the nature of tentative findings, due to the small sample size, but provide sufficient data to illustrate a methodology that could be applied to a much larger sample if information concerning mature career achievements of both fathers and sons is available. The result from this sample was possibly due to a shift in recruitment policies of the Big 8 , but any 
such shift has not been historically documented in New Zealand to date. In the USA, there was documented discrimination against second generation accounting graduates (i.e. children of recent immigrants) in the placement programme of the AIA in the 1920s, which favoured those from "acceptable social backgrounds for future leadership in the professions' most elite firms" (Miranti, 1990, p.125). A recent study in New Zealand, looking at recent data, examined whether the application forms used by the Big 8 have the potential to discriminate unfairly against applicants from working-class, non-professional socio-economic settings (Jacobs, 2003). He determined there were some inter-firm differences, with some firms, such as Deloittes, taking an explicitly meritocratic approach. However, all firms had particular emphasis on responsibility and teamwork, which may create class-bias, as such attributes may favour those who show leadership potential and contribution to sports-team activities. Both of these are particularly associated with private secondary school education in the United Kingdom. This study appears to support that such a policy change by firms occurred in 1960, although there is a lack of data on recruitment policies with such a historic dimension.

\section{Discussion and Conclusion}

The nature and extent of mobility influences evaluations that each person makes of the society in which they live, particularly pertaining to legitimacy of inequalities of both opportunities and conditions in which they live. For accountants, and partners in the bigger firms in particular, they perceive they are members of a professional class with an explicit set of goals and objectives that they pursue and believe. The potential for mobility into the professional class, and in particular into the Big 8 firms, is critical for their credentials; and these firms increasingly make transparent the equality of opportunities they offer to graduates.

This data from a professional class in post-World War II New Zealand suggests there has been a contraction of class mobility aligned to changes in preferred educational routes into the profession. Even though aspiring accountants did not have to complete a university degree or undertake full-time studies to gain membership of the profession, the younger group of this cohort (those born after 1942) all completed full-time degree study at universities. This cohort also provides evidence of a reduced level of class mobility into the profession from the blue-collar or skilled tradesmen's families. The older cohort, born between 1928 and 1946, completed part-time studies only, and only a few of them completed a degree. This older cohort shows a perceptible upward movement from lower socio-economic classes into the professional class.

This study reflects what Burrage et al referred to as "the unmistakable trend toward university-based professional training" (1990, p.216). They suggest that the relationship between universities and professional bodies is a neglected aspect of research on the professions. This study has illustrated an episode of resolution of tensions between the needs 
of aspiring accountants, and the universities' aspirations to draw commercial subjects into mainstream university activities.

Generally, the self-conscious democratization of education in the first half of the twentieth century was part of a broader pattern of social change in countries such as the United States, Australia and New Zealand. The increase in class mobility in New Zealand was similar to that in the United States (Oliver, 1969, p.164). At the same time, professional organisations took a variety of steps to ensure high educational standards for their members. The shift to university-based providers was not accompanied by any well-documented changes in educational standards required of entrants to the accounting profession. Another viewpoint is that the closure, which was the result of a shift in the processes of credentialism through fulltime university studies, was also to the benefit of society. The increasing information needs of society has been driven by both complex aspects of expanding global business, and technological changes which were interdependent with best practices in accounting and auditing.

This material suggests further research questions, such as an examination of recruitment policies of large firms to identify any preferences for new employees who had completed the full-time educational route. Future research could also identify the effect of a more recent movement against closure in the 1990s when the New Zealand profession allowed a class of Accounting Technicians (AT) to achieve College status within the newly re-named Institute of Chartered Accountants of New Zealand (previously the Society). This was accompanied by the requirement not only for CA aspirants to complete a degree, but also to complete four years tertiary education. Data concerning class mobility into the AT class, and movement from the AT into the CA college may provide further evidence of the 'constant flux'. Closure events may be further balanced by a thrust of the professional body to increase both the professional domain and the variety of membership classes.

This study has demonstrated the utility of dividing occupational classes into the disaggregate occupations within the professions. Although some attention is paid to studies of father-son progressions in other professions, such studies are rare in accountancy. The significance of anti-nepotism rules in partnership is another aspect which merits further investigation.

Three-generational data of mature career achievements would also provide valuable data to further document the flux in mobility, especially if it could be obtained from a number of different jurisdictions. It is hoped this study will stimulate research on the basis of threegenerational data with longitudinal disaggregation of the 'professional' class; thus further documenting the fabled and enabling 'stepping stone' function of accounting to the professional class, illustrated to a modest degree by this study. 



\section{Bibliography:}

Abbott, A., (1988), The System of Professions: an essay on the division of expert labor. Chicago: University of Chicago Press.

Auerbach, J., (1976), Unequal Justice: Lawyers and Social Change in Modern America, New York : Oxford University Press

Budge, E. G., (1960), “The Universities and Accountancy Education”, The Accountant's Journal, Vol. 39, pp.18-20.

Burrage, M., K. Jarausch and H. Siegrist, (1990), "An actor-based framework for the study of the professions" in Burrage, M. and Torstendahl, R. (eds.), Professions in Theory and History; rethinking the study of the professions, London: Sage, pp.203-225.

Calvert, M. A., (1967), The Mechanical Engineer in America 1830 - 1910: Professional Cultures in Conflict. Baltimore: The Johns Hopkins Press.

Carnegie, G. D., and J. R. Edwards, (2001), "The construction of the professional accountant: the case of the Incorporated Institute of Accountants, Victoria (1886)", Accounting, Organizations and Society, Vol.26, pp.301-325.

Chua, W. F., and S. Clegg, (1989), “Contradictory couplings: professional ideology in the organizational locales of nurse training", Journal of Management Studies, Vol.26, pp.103-127.

Chua, W.F., and C. Poullaos, (1998), "The dynamics of "closure" amidst the construction of market, profession, empire and nationhood: An historical analysis of an Australian accounting association, 1886-1903", Accounting, Organizations and Society, Vol.23, pp.155-187.

Collins, R. (1990), "Market Closure and the conflict theory of the profession", in Burrage, M. and Torstendahl, R. (eds.), Professions in Theory and History; rethinking the study of the professions, London: Sage, pp.24-43.

Cowan, T. K., (1960), “The Universities and Accountancy Education”, The Accountant's Journal, Vol.38, pp.395-398.

Crook, C. J., (1997), "Occupational returns to cultural participation in Australia”, Australian and New Zealand Journal of Sociology, Vol.33, pp.56-74.

Erikson, R., and J. H. Goldthorpe, (1992), The Constant Flux: A Study of Class Mobility in Industrial Societies, Oxford: Clarendon Press.

Fippard, N. B., (1960), "The Education and training of accountants", The Accountant's Journal, Vol.38, pp.399-404. 
Freedman, M., (1976), Labor Markets: segments and shelters. Montclair, New Jersey: Allanheld, Osmun.

Freidson, E., (2001), Professionalism - the Third Logic. Chicago: The University of Chicago Press.

Guerin, D., (2004), Personal Correspondence, January 13, 2005.

Hopper, E., (1981). Social mobility: a study of social control and insatiability, Oxford: Blackwell.

Jacobs, K., (2003), "Class Reproduction in Professional Recruitment: examining the accounting profession”, Critical Perspectives in Accounting, Vol.14, No. 5, pp.569-596.

King, F. H. E., (1962), Letter, The Accountant's Journal, Vol.41, p.9.

Larson, M. S., (1977), The Rise of Professionalism: a sociological analysis. Berkeley, LA, London: University of California Press

Lee, T. A., and S. A. Walker, (1996), "Scottish emigration and U.S. accountancy", The CPA Journal, Vol.66, pp.46-49.

Loeb, S. E., and P. J. Miranti, (2004), The Institute of Accounts. Nineteenth-century origins of accounting professionalism in the United States. London and New York:

Routledge New Works in Accounting History.

Miranti, P. J., (1990), Accountancy Comes of Age - The development of an American Profession, 1886 - 1940. Chapel Hill and London: The University of North Carolina Press.

Montagna, P.D., (1974), Certified public accounting: a sociological view of a profession in change. Houston: Scholars Book Company.

Murphy, R., (1984), “The structure of closure: a critique and development of the theories of Weber, Collins and Parkin”, British Journal of Sociology, 35, pp.547-567

Oliver, W. H., (1969), "Reeves, Sinclair and the Social Pattern”, in Munz, P., (ed.), The Feel of Truth, Wellington: A.H. and A. W. Reed.

Olssen, E., and H. James, (1999), "Social mobility and class formation: The worklife social mobility of men in a New Zealand suburb, 1902-1928", International Review of Social History, Vol.44, pp.419-449.

Pearson, D. G., and D. C. Thorns, (1983), Eclipse of Equality: Social Stratification in New Zealand Sydney, London, Boston: George Allen and Unwin. 
Sidebotham, R., (1962), “Education for Accountancy - Full-time or part-time?”, The Accountant's Journal, Vol.40, pp.322-325.

Sinclair, K., (2000), A History of New Zealand, Auckland: Penguin.

Sinclair, K., (ed.), (1990), The Oxford Illustrated History of New Zealand, Auckland: Oxford University Press.

Stevens, R., (1971), American Medicine and the Public Interest. New Haven: Yale University Press.

Stevens, R. B., (1983), Law School - Legal Education in America from the 1850s to the 1980s. Chapel Hill and London: North Carolina Press.

Thompson, G. E., (1924), "Education for a Business Career”, The Accountant's Journal, Vol.3, pp.102-103.

Walker, S. P., (1988), The Society of Accountants in Edinburgh 1854 - 1914: A Study of Recruitment to a new profession. New York and London: Garland.

Walker, S. P., (1991), "The Defence of Professional Monopoly: Scottish Chartered Accountants and 'Satellites in the Accountancy Firmament' 1895 - 1914", Accounting, Organizations and Society, Vol.16, pp.257-283.

Walker, S. P., (1995), "The genesis of professional organization in Scotland: A contextual analysis", Accounting, Organizations and Society, Vol.20, pp.285-310.

Walker, S. P., and K. Shackleton, (1998), "Corporatism and structural change in the British accountancy profession, 1930 - 1957”, Accounting, Organizations and Society, Vol.20, pp.467-503.

Weber, Max, (1968), Economy and Society, New York: Bodminster Press.

Wellington Public Accountants Committee, (1962), "Education for Accountants - full-time or part-time?", The Accountant's Journal, Vol.41, pp.8-9.

Western, M., (1994), “Class Structure and inter-generational class mobility: a comparative analysis of nation and gender", Social Forces, Vol.73, pp.101-133. 
Table 1: Inter-generational data on Parents and Sons in this study

\begin{tabular}{|c|c|c|c|c|c|c|c|c|c|c|}
\hline \multicolumn{5}{|c|}{$\begin{array}{l}\text { Educational data relating to the } \\
\text { subjects in this study }\end{array}$} & \multicolumn{6}{|c|}{ Parent's occupation } \\
\hline $\begin{array}{l}\text { Tertiary } \\
\text { studies }\end{array}$ & $\mathrm{N}$ & \begin{tabular}{|l|} 
Gained \\
degree
\end{tabular} & \begin{tabular}{|l|} 
Birth \\
dates
\end{tabular} & \begin{tabular}{|c|} 
Average \\
age at \\
time of \\
interview \\
\end{tabular} & $\begin{array}{c}\text { Professional } \\
- \\
\text { Accountant }\end{array}$ & $\begin{array}{c}\text { Other } \\
\text { professional }\end{array}$ & $\begin{array}{c}\text { Entrepreneurial: } \\
\text { sole proprietor } \\
\text { petit } \\
\text { bourgeoisie } \\
\end{array}$ & $\begin{array}{l}\text { Official and } \\
\text { supervisory, } \\
\text { and semi- } \\
\text { professional }\end{array}$ & \begin{tabular}{|c|} 
Skilled \\
tradesman
\end{tabular} & \begin{tabular}{|c} 
Semi \\
skilled \\
and \\
unskilled \\
\end{tabular} \\
\hline $\begin{array}{l}\text { Part- } \\
\text { time }\end{array}$ & 25 & $40 \%$ & $\begin{array}{l}1928- \\
1946\end{array}$ & 66 & 5 & 3 & 7 & 3 & 4 & 3 \\
\hline $\begin{array}{l}\text { Part- } \\
\text { time and } \\
\text { full-time }\end{array}$ & 4 & $75 \%$ & $\begin{array}{c}1935- \\
1952\end{array}$ & 59 & & 1 & 2 & & 1 & \\
\hline $\begin{array}{l}\text { Full- } \\
\text { time }\end{array}$ & 11 & $100 \%$ & $\begin{array}{l}1942- \\
1953\end{array}$ & 56 & 4 & 4 & 3 & & & \\
\hline $\begin{array}{l}\text { Total } \\
(\mathrm{N})\end{array}$ & 40 & & & 63 & 9 & 8 & 12 & 3 & 5 & 3 \\
\hline
\end{tabular}




\section{Appendix 1. Selection of the Oral History Cohort}

In May 2002 a survey was administered to members of the Institute of Chartered Accountants of New Zealand who were partners, continuously, in the biggest firms between $1982-1992$. Added to this group were: members who were partners of Ernst and Whinney and Arthur Young during the merger period; members who were partners of Touche Ross, Lawrence Anderson Buddle, and Kendons during 1982 - 1992; and three Institute officials involved with partnership practice issues. The survey encompassed the following partners for whom addresses were identified from the Institute membership list:

124 partners who had switched between large firms

plus all other partners anytime $1982-1992$ in

Lawrence Anderson Buddle

Touche Ross

Kendons

plus 83 partners who stayed in one firm from 1982 - 1992:

Kirk Barclay/Spicer and Oppenheim

Price Waterhouse

Coopers and Lybrand

Peat Marwick

Deloittes

Plus Partners who were in Ernst and Whinney or Arthur Young over the merger period

(at least for more than one year in the 1986 - 1990 years; some were there for the whole period 1982 - 1992)

Of these 514 partners, 488 addresses were identified. The survey was conducted in May 2002; and 108 responded. Members who were retired were asked in the survey if they would consider participation in an Oral History Project.

36 retired respondents expressed willingness to receive more information on this stage. All 26 retired members who eventually consented to Oral History participation were interviewed (July - December 2002). However, there were gaps in the cohort, in that coverage of all firms was insufficient. A further 31 non-retired respondents who had answered positively to the question: "Are you willing to be contacted further for any clarification of points raised in your response, or for meeting in group discussion with a focus group, if appropriate?" were asked if they would participate in the Oral History cohort. Three other interviewees were also approached from recommendations during the project. Fourteen of this second group agreed, resulting in a cohort of 40. One was subsequently too ill and one joined in an interview. There were 40 interviewees. There were very few female partners at this time, and this sample reflects this. Four females were in the sample of 488 partners, but none wished to be interviewed.

The manner in which this cohort was a self-selected raises the fundamental question of the extent to which the educational routes experienced by this group of accountants is typical or representative of young accountants over those decades. All of the survey respondents and participants in this study were invited to read research outputs from this project on the website www.greenink.co.nz. Any response was facilitated by a direct e-mail link from the website. One participant sent in extensive commentary after reading this paper, but this was not in the nature of rebutting the assumption that these experiences were typical. Part of his response was: "I found that paper a very interesting read, and it stirred a few memories about "student" life in those times...I perceive a few factors other than those covered in your paper 
influencing progress or lack of it towards full-time study. I see it as a trend that progressed as quickly as it could given the then conditions. One of those conditions was the evolution of accounting theory; my recollection of the early 1950s is that putting the debit on the left, and a thorough familiarity with Staples' Tax Guide, was about as far the theory went - so what was there to learn at a university? However there was little doubt in the 1970s that full-time study was preferable, both for students and employers". The trend to which this correspondent alludes is an important one, but a different aspect of the evolution of accounting education the increasing teaching of accounting theory and outside the scope of this study of class mobility.

The claim that this study sample is self-selected was partially balanced by inviting responses to early drafts; and also by identifying, in the narratives selected, the extent to which these were typical or atypical of the cohort. Length constraints preclude more narratives; those chosen illustrate a number of commonalities in the analysis. Although it may have been interesting to interview more members who combined a part-time and full-time education, this was not a variable on which selection was based. Selection was based on being a partner in a large firm in the 1980s. Seeking participants from earlier or later decades would have resulted in a very different profile of educational routes, and one that would be of considerable interest. This study offers a baseline with which to compare such older or younger cohorts. 